\title{
Body Weight and Energy Intake and Expenditure in Bariatric Surgery
}

\author{
Maria Rita Marques de Oliveira, Patrícia Fátima Sousa Novais, \\ Karina Rodrigues Quesada, Carolina Leandro de Souza, \\ Irineu Rasera Junior and Celso Vieira de Souza Leite \\ UNESP - Universidade Estadual Paulista - Botucatu-SP, \\ Clinica Bariátrica - Hospital dos Fornecedores de Cana, Piracicaba-SP, \\ Brazil
}

\section{Introduction}

Body weight is ultimately determined by energy homeostasis, a complex process of regulation. Homeostasis is one of the greatest challenges for understanding the etiology, treatment and prevention of obesity (Hill, 2006). The high rate of weight regain in individuals who undergo weight loss treatments is proof of this (Melo et al., 2008). Even among morbidly obese individuals submitted to more radical treatments, such as surgery, weight regain sometimes occurs [Fogaça, 2009]. In this sense, energy intake and expenditure assessments represent extremely important factors, both for studies and as an aid in the process of caring for the obese.

Given the premise that all obesity treatment methods are based on reducing food intake and increasing energy metabolism, the present chapter intends to discuss the variables in the energy balance equation using the results from works of the research group Bariatric Surgery and Metabolism of Paulista State University - UNESP, Campus Botucatu, São Paulo, Brazil, and of the Bariatric C.inic of Piracicaba, São Paulo, Brazil, as reference. Components of energy metabolism and indirect calorimetry will be discussed.

Indirect calorimetry is a reference method that has been used for almost 100 years for measuring energy intake in humans during resting or physical activity. Studies using indirect calorimetry allow assessing the effects of energy intake, physical activity and other factors involved in the energy metabolism on the total body mass of obese individuals or its compartments. Here, indirect calorimetry was used to assess the agreement between itself and prediction formulas, to discuss the effects of food restriction and to assess energy intake underreporting by obese women submitted to food intake surveys. Indirect calorimetry data also allow one to discuss the effects of weight loss and body mass index on energy expenditure and biochemical indicators of glucose and fat metabolism. These studies allowed the elucidation of some energy metabolism particularities of individuals who undergo bariatric surgery, as well as the proposition of some hypotheses for new studies. 


\section{Energy expenditure and food restriction}

Daily total energy expenditure (TEE) is the term used for defining the amount of energy necessary for an organism to perform its vital functions and activities of daily living. TEE consists of the resting energy expenditure (REE), which is the energy used by the body during rest, that is, in bed, under comfortable environmental conditions (60-75\% do TEE), by food-induced thermogenesis, which is the heat effect of foods (5-15\% do GET) and by energy spent on physical activities, considered the most variable component of the TEE and which can contribute to a significant amount of the energy spent by very active individuals (Meirelles \& Gomes, 2004, Prentice, 2007).

Indirect calorimetry is a noninvasive technique used to measure the volume and concentration of the gases inhaled by the lungs and allows the calculation of the amount of oxygen $\left(\mathrm{O}_{2}\right)$ consumed and the production of carbonic gas $\left(\mathrm{CO}_{2}\right)$. These values may stem from the baseline energy expenditure (BEE), the REE and the respiratory quotient (RQ), given by the equation: exhaled $\mathrm{CO}_{2}$ /inhaled $\mathrm{O}_{2}$ (Simyrnios \& Curley, as in Rippe et al., 1996). There is a difference between BEE and REE. The BEE corresponds to the energy expenditure that occurs during a 12- to 14-hour fast and with the individual resting in the supine position, awake and immobile, under comfortable environmental conditions. This standardized metabolic state corresponds to the situation in which foods and physical activity have the least influence on metabolism (Institute of Medicine, 2005). Meanwhile, REE is obtained while the individual is awake in the supine position and includes the energy used during awakeness plus the energy used for food metabolism, or thermogenesis (Institute of Medicine, 2005). Both BEE and REE are influenced by gender, age, nutritional status and endocrine problems.

Thermogenesis, or thermal effect of foods, corresponds to the increase in energy expenditure after food intake for digestion to occur and for the substrates to be transformed and stored. It represents roughly 5 to $10 \%$ of the TEE (Institute of Medicine, 2005; Prentice, 2007). Thermogenesis intensity and duration are determined primarily by the amount and composition of the foods consumed (Flatt, as cited in Bray, 1978). The use of proteins demands more energy than the use of carbohydrates, which demands more energy than the use of fats (Institute of Medicine, 2005, 1998, Larson et al., 1995). High-fat diets promote a low RQ. For carbohydrates, the RQ equals 1.00; for proteins, 0.82; and for fats, 0.70 . For mixed diets, the RQ of 0.85 is usually used (Rosado \& Monteiro, 2001).

Physical activity is the most variable component of energy expenditure, varying both from individual to individual and from one day to the next. In inactive individuals, it represents roughly $15 \%$ of the TEE, while in active individuals it may exceed $30 \%$ of the TEE (World Health Organization, 1998). Physical activity can lead to steep increases in TEE because of the energy cost to perform the exercise and to recover from the exercise, or in the long-term, by changing the REE by increasing the amount of lean mass (Hill et al., 1995). The level of physical activity is commonly described as the ratio between TEE and REE (TEE:REE). This ratio is known as the level of physical activity level (PAL) and is used to asses physical activity habits as a component of daily energy expenditure (Institute of Medicine, 2005).

The doubly-labeled water with deuterium and oxygen-18 technique, although less accessible, has been used increasingly for TEE assessment. The method, based on the principle of isotope dilution, consists in the ingestion of water containing ${ }^{2} \mathrm{H}_{2} \mathrm{O}$ and $\mathrm{H}_{2}{ }^{18} \mathrm{O}$. 
The labeled elements are then measured in organic fluids, namely blood and urine. The equations for predicting the energy requirements proposed by the Institute of Medicine (2005) in the Dietary Reference Intakes (DRI) stemmed from studies using doubly-labeled water in normal weight, pre-obese and obese populations. Studies with doubly-labeled water have made the generalized low-metabolism hypothesis associated with obesity less evident.

Many researchers have observed that obese individuals, contrary to the expected, present a high REE, that is, their metabolic rate is not low (Das et al., 2004; Prentice, 2007). Obese individuals present a higher amount of lean mass, the main REE determinant (Prentice et al., 1986; Prentice, 2007; Ravussin et al., 1986). The occurrence of less energy expenditure in other components of the energy metabolism has also been studied in obese individuals. Danforth (1985) noticed reduced thermogenesis from foods. Other authors have showed that REE is influenced by regular physical activity, diet, blood pressure, as well as hormones and cytokines (Trayhurn et al., 1995; Hardie et al., 1996). Genetic predisposition must also be considered a determinant of energy expenditure.

Many genes of the molecular components of physiological systems that regulate energy balance are involved in obesity (Duarte et al., 2007; Yurtcu et al., 2009). Examples of this are the polymorphisms found in genes of the uncoupling proteins 2 and 3 (UCP2 and UCP3) and in leptin receptors (LEPR) (Jacobson et al., 2006). Polymorphism Gln223Arg of the gene LEPR, for example, has already been associated with obesity in a sample of the Brazilian population, and it presented a strong association with body mass index - BMI (Duarte et al., 2007). Studies with rats show that leptin can reduce adiposity both by promoting changes in eating habits and by increasing energy expenditure (Halaas et al., 1995). Ghrelin, a gastric peptide involved in the regulation of satiety and oxidation of energy substrates, is of interest for genetic studies on the weight loss mechanisms promoted by bariatric surgery (Marzullo et al., 2004). The regulation of ghrelin effects on hypothalamic neurons has been suggested as the most important mechanism by which leptin controls energy intake and body weight (Sahu, 2004).

In some people, low energy expenditure could be explained by adaptive thermogenesis, which would occur naturally or as a consequence of dietary restrictions. There is evidence that low energy intake is a predictor of weight gain and that, in individuals who undergo weight loss therapies, decreased REE is associated with weight regain over time (Doucet et al. 2000). In this sense, food restriction promotes adaptive physiological mechanisms that serve as a defense of the body to maintain body weight, resulting in less energy expenditure (Negrão \& Licino, 2000). Hence, food restriction produces weight loss under adaptive conditions. The Institute of Medicine (2005), in the energy DRI assumes a reduction of $7.2 \mathrm{Kcal}$ for each lost gram, which corresponds to $16.6 \mathrm{Kcal}$ of TEE reduction at each kilogram lost. Furthermore, it considers a reduction of $8.4 \%$ of the TEE after 10 weeks of food restriction because of the adaptation to food restriction. In our studies, we have observed that in fact there is not a linear relationship between energy intake and body weight homeostasis. As shown by Figure 1, there is no correlation between total dietary energy and weight loss among obese women but there is a weak correlation between the reduced proportion of the total energy (TE) intake. This shows how relevant it is to personalize the diet plan considering the adaptation of the energy metabolism to restrictive diets. Caution is also warranted when prescribing excessively restrictive diets. Another relevant finding of our study group that corroborates this statement 
was that there is a negative correlation between the reported number of attempts of losing weight and the resting energy expenditure measured by indirect calorimetry, assessed in 100 women in the waiting line for bariatric surgery.

Intake (Kcal)

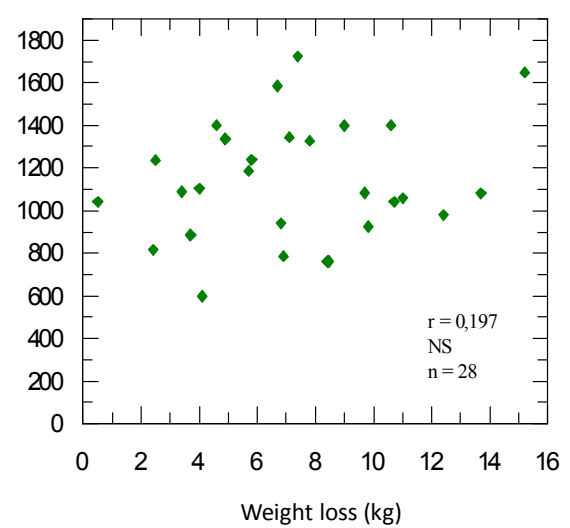

Intake Reduction (\%)

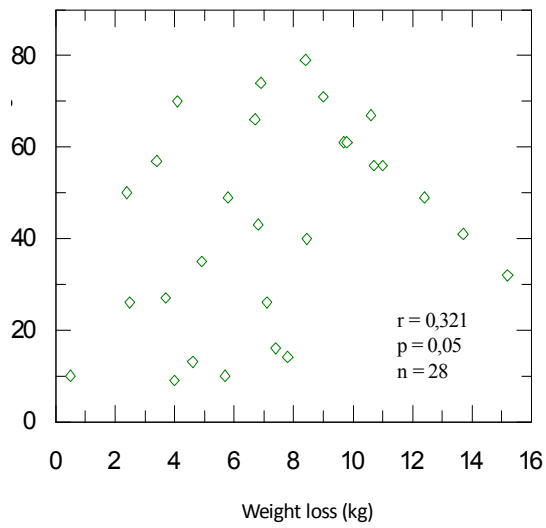

Fig. 1. Correlation between the absolute value (left) and the proportion of reduction of the habitually consumed energy in obese women after 2 months of a low-calorie diet $(n=28)$. SPEARMAN and RANK tests, with probability considered significant when $\mathrm{p}<0.05$.

In studies done in the region of Piracicaba, São Paulo, Brazil (Dallemole, 2006; Souza, 2006; Fogaça, 2009) with women recruited from the general population and those who had undergone bariatric surgery, as shown in Chart 1, energy expenditure increases with body weight. However, in relative terms, there is less energy expenditure by unit of weight as weight increases. Operated women present absolute and relative REE lower than the other women.

Since the first equation proposed by Harris and Benedict in 1919, many equations to predict REE were developed based on indirect calorimetry, and also to estimate TEE by combining the expenditure with physical activities with REE. The formulas used for predicting energy requirements have been widely used in clinical practice.

A cross-sectional study was done by our group with 51 women aged from 28 to 61 years submitted to banded or not bariatric surgery (Roux-en-Y gastric bypass, RYGB) 5.1 11.7 years before the study, all of them with stable weight. The measured REE was confronted with the values of the respective predictive equations obtained from regression studies in a number of different populations (Harris \& Benedict, 1919; Schofield, 1985; Food and Agriculture Organization, World Health Organization \& Organização das Nações Unidas, 1985; Owen et al., 1986; Mifflin et al., 1990, Luis et al., 2006). When the measurements were compared (Figure 2), the values obtained by indirect calorimetry were below those obtained by the equations, and when the results were organized in increasing order of the value obtained by calorimetry (Figure 3), there was great similarity in the behavior of the lines constructed with the sequence of the results of the equations, but they diverged from those constructed with the results of calorimetry. Thirty-one $(77.5 \%)$ women presented a median REE measured by indirect calorimetry below the REE estimated by the Harris \& Benedict (1919) equation, indicating some women in the group had low metabolism. Weijs \& Vansant 
(2010) assessed 27 prediction equations in relation to the indirect calorimetry data from Belgium women and concluded that more specific equations are necessary for women whose $\mathrm{BMI}>30 \mathrm{Kg} / \mathrm{m}^{2}$.

\begin{tabular}{|l|c|c|c|c|l|}
\hline Population & $\begin{array}{c}\mathrm{BMI} \\
\mathrm{Kg} / \mathrm{m}^{2}\end{array}$ & $\mathrm{n}$ & $\begin{array}{c}\text { REE } \\
\text { Mean } \pm \text { SD }\end{array}$ & $\begin{array}{c}\text { REE/BW } \\
\text { Mean } \pm \text { SD }\end{array}$ & \multicolumn{1}{|c|}{ Reference } \\
\hline \multirow{4}{*}{ Surgery-naive } & $<25$ & 22 & $1216 \pm 214$ & $22 \pm 3$ & Dallemole, 2006 \\
\cline { 2 - 6 } & $25-30$ & 11 & $1322 \pm 212$ & $23 \pm 3$ & Dallemole, 2006 \\
\cline { 2 - 6 } & $30-35$ & 13 & $1425 \pm 167$ & $19 \pm 3$ & Dallemole, 2006 \\
\cline { 2 - 6 } & $>35$ & 35 & $1600 \pm 430$ & $16 \pm 4$ & Souza, 2006 \\
\hline \multirow{2}{*}{$\begin{array}{l}\text { Before and 3 months } \\
\text { after surgery }\end{array}$} & $46 \pm 6$ & 21 & $2006 \pm 376$ & $17 \pm 4$ & Cesar et al., 2008 \\
\cline { 2 - 6 } $\begin{array}{l}\text { 2 or more years after } \\
\text { surgery }\end{array}$ & $39 \pm 6$ & 21 & $1763 \pm 310$ & $18 \pm 3$ & César et al., 2008 \\
\cline { 2 - 6 } & $<30$ & 18 & $1046 \pm 264$ & $15 \pm 4$ & Fogaça, 2009 \\
\hline
\end{tabular}

Chart 1. Energy expenditure determined by indirect calorimetry in women recruited in Piracicaba, São Paulo, Brazil.

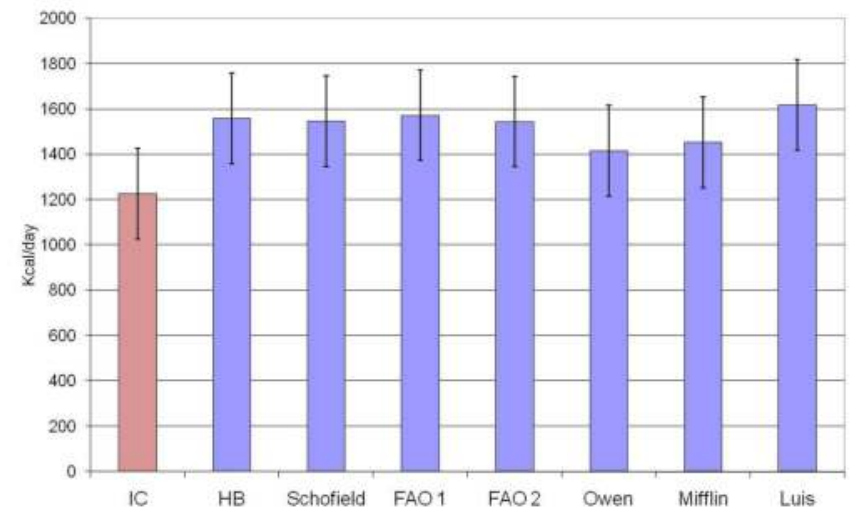

Fig. 2. Comparison of the resting energy expenditure measured by indirect calorimetry (IC) and estimated by different equation in women after two years of bariatric surgery (HB= Harris \& Benedict; $\mathrm{p}<0.01$ means compared with ANOVA; $\mathrm{p}<0.01$ others compared with the Tukey test; ${ }^{* *} \mathrm{p}<0.05$ in the comparison with FAO 1 and Luis by the Tukey test).

The metabolic state can be classified as normal, high or low, by comparing the measured REE with the estimated REE according to the mean of a reference population, using a variation coefficient of 15\% (Food and Agriculture Organization, World Health Organization \& Organização das Nações Unidas, 1985). In this sense, very low REE values deserve better investigations regarding adaptation to metabolic restriction after bariatric surgery.

These equations are based on body mass, height, age, gender and specific body composition markers, such as body surface area, lean mass, fat mass, total body potassium, among others (Rocha et al., 2005). The equations have been used in underweight, overweight, obese and morbidly obese individuals and also in those with specific diseases. However, interpersonal 
variation shows that much caution is necessary for estimating REE by the existing prediction equations, since it has been shown that they do not always estimate REE correctly (Frankenfield \& Yousey, 2005) resulting in errors when estimating the energy requirements of individuals and populations (Duarte et al., 2007). More studies are necessary to state if the proportion of women with low metabolism who underwent bariatric surgery was in fact greater than that of the surgery-naive population, obese or otherwise, since there are not enough data from the population who lives in the same environmental conditions as that of the present study.

Although much has been done since Harris \& Benedict (1919), the current formulas for estimating REE and TEE (that takes into account the energy spent in physical activities) are very limited and tend to overestimate the results.

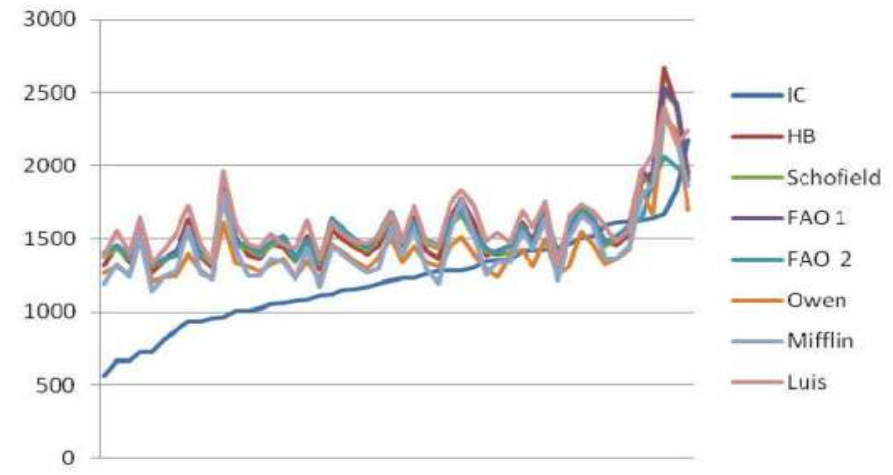

Fig. 3. Illustration of the resting energy expenditure, in increasing order, measured by indirect calorimetry (IC), in relation to that estimated by different equations among women two years or more after bariatric surgery $(n=51)$.

\section{Energy intake}

One of the most challenging aspects of the science and practice of nutrition and dietetics is the measurement of energy and nutrient intakes, given the limitations of the methods to correctly measure food intake (Subar et al., 2006). Dietary surveys are used as indirect methods for assessing nutritional status. However, these instruments are subject to mistakes inherent to the individual and data analysis and use (Beaton, 1994; Slater et al., 2004). Individual quantitative and qualitative food intake may be estimated by different diet survey methods. There are retrospective methods where individuals recall the foods they have eaten, such as the Food Frequency Questionnaire (FFQ) and the 24-hour Recall (24hR). And the methods in which the individual records, when he eats, all the foods he ate, thereby creating a food diary (Gibson, 2005).

Intraindividual error sources, because of the variability of the food intake pattern, or interindividual error sources, stemming from the distribution of the population's requirements, together with a small number of days of observation, have a great impact on the reliability of food intake data analysis (Nusser et al., 1996). Hence, intake assessment studies will always be reporting the apparent intake of the individual and not the real intake, but they can be statistically adjusted to approximate the actual intake (Institute of Medicine, 2005). 
Possible error sources can distort information about food intake, such as the perception of what is eaten, the interviewee's memory, the effects stemming from age, gender and interview environment, daily diet variation and seasonality, submission to data collection can affect the intake pattern and veracity of the information, the ability of the interviewer to obtain information and the disposition to collaborate with the investigation (Witschi, as in Willett, 1990). Practically, all dietary assessment studies are based on self-reporting of food intake, which can be biased, resulting in under- or overreporting of real energy intake (Black et al., 1991; Black, 2000), being able to seriously distort the interpretation of the study results (Rennie et al., 2006).

Underreporting has been associated with a number of different individual characteristics, including gender, body mass index, age, ethnicity, race, smoking, education level, social class, depression and physical activity (Johansson, et al., 2001; Scagliusi, et al., 2003; Scagliusi et al., 2008; Maurer et al., 2006, Maurer et al., 2008; Mendez et al., 2011). The desire to be socially accepted and body dissatisfaction have also been associated with underreporting of food intake (Tooze et al., 2004; Maurer et al., 2006; Scagliusi, 2007). Excess weight may be one of the greatest determinants of subnotification (Johansson et al., 2001; Johnson, 2002; Huang, et al., 2005; Bazanelli et al., 2010).

In individuals who are in energy balance, energy intake should correspond to the TEE. Thus, the doubly labeled water can be used to validate the energy obtained through dietary surveys. However, this method is unviable in large studies because of its cost and because it is technically challenging for use in routine validation of energy intake (Schoeller, 1999; Livingstone \& Black, 2003).

As an alternative, other methods for identifying underreporting can be used, such as the comparison between reported energy intake $\left(\mathrm{EI}_{\mathrm{rep}}\right)$ with TEE, when both are expressed in multiples of the REE, using a confidence interval for statistically comparing $\mathrm{EI}_{\text {rep }}$ :REE with the level of PAL. During weight stabilization, $\mathrm{EI}_{\mathrm{rep}}$ :REE theoretically is equal to TEE:REE. The ratio TEE:REE is also known as PAL, then the equation may be rewritten as $\mathrm{EI}_{\text {rep }}: \mathrm{REE}=$ PAL (Goldberg, et al., 1991).

As described by Black 2000, the cut-off point of the ratio $\mathrm{EI}_{\text {rep }}: \mathrm{REE}$ should be calculated for the group being studied, since below this level it is statistically unlikely that the mean energy intake reported represents the real consumption, according to the equation below:

$$
\text { Cut }- \text { off point }=\mathrm{PAL} \times \exp \left[\mathrm{SD}_{\min } \times \frac{(\mathrm{S} / 100)}{\sqrt{\mathrm{n}}}\right]
$$

Where $\mathrm{SD}$ is the standard deviation. When $95 \%$ of the confidence interval is used $\left(\mathrm{SD}_{\min }=-2\right)$ or $99.7 \%\left(\mathrm{SD}_{\min }=-3\right)$; $\mathbf{n}$ is the number of individuals in the study, but when this formula is used to individually detect underreporting, $n=1$. $S$ is the factor that takes into consideration the variation of all components of the equation and is given by:

$$
S=\sqrt{\left[\left(\frac{\mathrm{CV}_{\text {EIrep }}^{2}}{\mathrm{~d}}\right)+\left(\mathrm{CV}^{2}{ }_{\text {REE }}\right)+\left(\mathrm{CV}_{\text {PAL }}^{2}\right)\right]}
$$

Where $\mathrm{VC}_{\mathrm{EIrep}}$ is the intra-individual energy intake variation coefficient; $\mathbf{d}$ is the number of days that the survey was administered; $\mathrm{VC}_{\mathrm{REE}}$ is the intra-individual variation coefficient of 
repeated $R E E$ measurements and $C V_{\mathrm{PAL}}$ is the intra-individual variation coefficient of the level of physical activity.

Recently, other authors (Huang, 2005; Mendez, et al., 2011), assessed the underreporting phenomenon comparing $\mathrm{EI}_{\text {rep }}$ with estimated TEE using the DRI equations (Institute of Medicine, 2005), adjusting the intra-individual variation of the equation components. The cut-off point is calculated for the study group in percentage (\%EI:TEE).

\begin{tabular}{l|ccc|ccc|c}
\hline \multirow{2}{*}{ Energy and macronutrients } & \multicolumn{3}{|c|}{ Before surgery } & \multicolumn{3}{c|}{ After surgery } & \multirow{2}{*}{ n=35 } \\
\cline { 2 - 7 } & median & $25 \%$ & $75 \%$ & median & $25 \%$ & $75 \%$ & \\
\hline Energy (Kcal) & 2780 & 1037 & 6338 & 1346 & 673 & 2981 & 0.000 \\
Carbohydrates (g) & 320 & 115 & 1031 & 166 & 68 & 428 & 0.000 \\
Fats (g) & 110 & 28 & 395 & 51 & 20 & 104 & 0.000 \\
Proteins (g) & 104 & 38 & 302 & 51 & 15 & 89 & 0.000 \\
Energy distribution & & & & & & & \\
Carbohydrates (\%) & 50 & 28 & 72 & 51 & 38 & 61 & 0.387 \\
Fats (\%) & 38 & 14 & 56 & 34 & 25 & 49 & 0.034 \\
Proteins (\%) & 16 & 9 & 23 & 15 & 8 & 25 & 0.226 \\
\hline
\end{tabular}

$\mathrm{p}=$ Mann Whitney test used for comparing energy and macronutrient intakes before and after surgery

Table 1 . The energy and macronutrient intakes of women before surgery and two or more years after surgery, Pircacicaba-SP, Brazil.

\begin{tabular}{lccccc}
\hline & Mean & $\begin{array}{c}\text { Standard } \\
\text { deviation }\end{array}$ & Median & $\begin{array}{c}\text { First Quartile } \\
\mathbf{( 2 5 \% )}\end{array}$ & $\begin{array}{c}\text { Third Quartile } \\
\mathbf{( 7 5 \% )}\end{array}$ \\
\hline EI $_{\text {rep }}$ & 1428 & 523 & 1334 & 1147 & 1678 \\
ER & $2786^{*}$ & 524 & 2812 & 2389 & 3036 \\
Harris\&Benedict (1919) & $1445^{*}$ & 152 & 1445 & 1376 & 1604 \\
REE & 1188 & 276 & 1209 & 1023 & 1376 \\
PAL & 1,45 & 0,22 & 1,42 & 1,28 & 1,56 \\
EI $_{\text {rep }}:$ REE & 1,27 & 0,57 & 1,08 & 0,86 & 1,66 \\
\hline
\end{tabular}

$\mathrm{EI}_{\mathrm{rep}}=$ reported energy intake, $\mathrm{ER}=$ estimated energy requirement, $\mathrm{REE}=$ measured resting energy expenditure, $\mathrm{PAL}_{\mathrm{est}}=$ estimated level of physical activity.

${ }^{*} p<0.000$ in the paired t-test between EIrep and ER and between Harris \& Benedict (1919) and REEmeasured.

Table 2. Energy intake and expenditure variables in women more than two years after bariatric surgery $(n=40)$.

Among the bariatric patients we studied, mean reported energy intake before surgery corresponds to half the intake reported after surgery (Table 1). In the comparison, the 
proportion of macronutrients in the energy of the diet varied little. The operated women consumed a fat proportion in the daily intake a little smaller than those in the waiting line for surgery. Those in the waiting line for surgery reported consuming a fat proportion above the recommended proportion (Institute of Medicine, 2005), while the operated women reported consuming a proportion close to the upper limit. About the data presented by Table 1, one may ask how much they correspond to reality based on the analysis presented by Table 2 given the discrepancy between the measured expenditure and reported intake. The data presented in Table 1 were obtained from 24-hour recalls on nonconsecutive days, one of the days being on a weekend. The data in Table 2 stem from indirect calorimetry, and the total energy requirement was calculated by the DRI formula (Institute of Medicine, 2005). Among these women, the $\mathrm{EI}_{\mathrm{rep}}: \mathrm{REE}$ and PAL values that, in theory should agree, present only a small correlation (Figure 4)

Our data (Table 2 and Figure 3) show that energy intake divided by resting energy expenditure $\left(\mathrm{EI}_{\mathrm{rep}}: \mathrm{REE}\right)$ was not compatible with the level of physical activity (PAL $\left.\mathrm{P}_{\mathrm{est}}\right)$ of the studied population. On the other hand, this can be explained by overestimating the reported physical activity which composes the $\mathrm{PAL}_{\text {est }}$ calculation. It may also be related to a substantially greater energy intake than that reported. Although one may not expect absolute agreement on this datum, since there are measurement errors in all elements of the equation $\left(\mathrm{EI}_{\mathrm{rep}}: \mathrm{REE}=\mathrm{PAL}\right)$. The fact is that the studied women were in a stable weight condition and reported consuming half the estimated energy requirement (RE). This leads us to the generalization that the scale is still the best instrument for assessing the adequacy of energy intake. That is, if the individual is involuntarily gaining weight, it is because he is consuming more energy than he needs. However, it is not convenient to give up trying to solve this difficult issue, which is to know the values of the two sides of this balance, which for now remain obscure. This information can help to explain, for example, weight recovery after bariatric surgery, which, in most cases, is accompanied by intake underreporting.

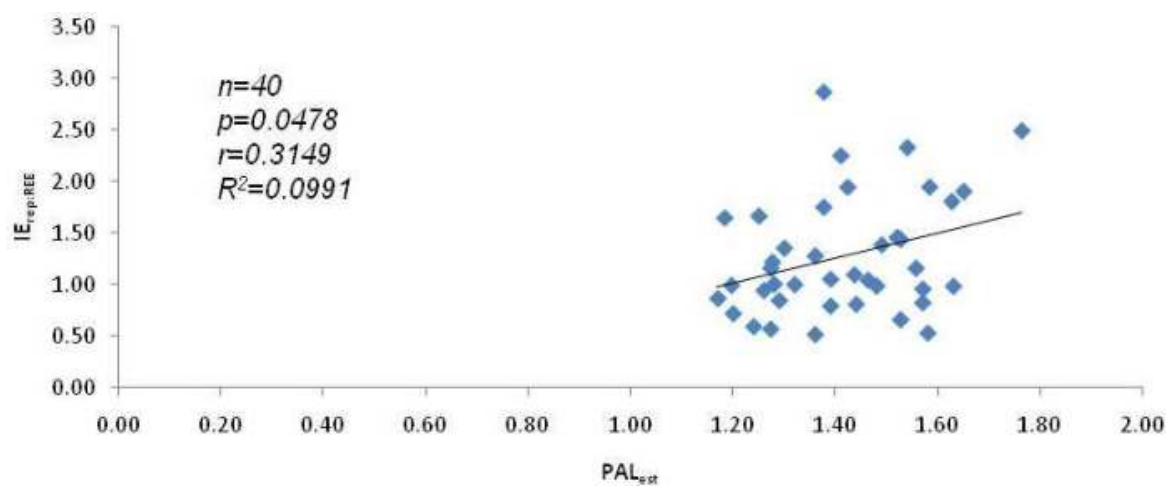

Fig. 4. Correlation between the estimated level of physical activity (PAL $\mathrm{PLst})$ and the ratio Energy Intake/Resting Energy Expenditure $\left(\mathrm{EI}_{\text {rep }} / \mathrm{REE}\right)$ in women more than two years after bariatric surgery $(n=40)$.

\section{Body mass}

There is a consensus that lean mass (LM) is the greatest determinant of energy expenditure, since it is metabolically more active than fat mass (Ravussin et al., 1986). Meanwhile, the 
differences in the volume of fat mass (FM), age and gender would have little effect on energy expenditure (Ravussin et al., 1986). Much has been discussed if an REE reduction could precede obesity; however, some researchers have rejected this hypothesis (Prentice, 2007). On the contrary, obese individuals present a high REE, that is, they do not have a low metabolism (Das et al., 2004; Hams et al., 2009; Prentice, 2007). This may occur because these individuals present a greater amount of lean mass, main determinant of the REE (Prentice, 2007; Prentice et al., 1986; Ravussin et al., 1986). Libel et al. (1995) assessed the energy expenditure during 24 hours and the REE in obese individuals and individuals who had never been obese in their habitual weights; after gaining $10 \%$ of the body weight by consuming a hypercaloric diet; or after losing 10 to $20 \%$ of the body weight by consuming a hypocaloric diet. They found that energy expenditure changed in both groups, of obese and nonobese individuals, after the change in the body weight. A $10 \%$ increase or reduction in habitual body weight causes an increase or reduction, respectively, of $15 \%$ in the 24 -hour energy expenditure corrected for body weight. They also verified that TEE presented a positive correlation with LM and FM. The positive correlation between the total body mass of obese individuals and TEE has been explained by the increase in energy necessary for moving this mass (Institute of Medicine, 2005).

Reduction of LM associated with weight loss is also discussed, and that the reduction of LM would result in a reduction of TEE, thus the importance of exercising during weight loss. Tamboli et al. (2010) found a LM loss in the order of $27.8 \%$ one year after Roux-em-Y gastric bypass and associated this loss with the reduction of the TEE of these patients. In another study done in obese individuals after weight loss, concomitantly with REE reduction, there was a significant reduction of LM (Hill et al., 1987).

Active individuals present a significantly higher REE than inactive individuals of the same weight (Matzinger et al., 2002). There is the hypothesis that this occurs because of the amount of LM, which is greater in active individuals (Tappy et al., 2003). The REE differences in body weight in many individuals like men, women or athletes normally disappear when REE is considered in relation to LM (Institute of Medicine, 2005).

Based on these studies it is possible to verify that body composition, especially LM, significantly affects REE and TEE, both in obese and nonobese individuals. Current knowledge allows us to state that there is little difference between energy expenditure by unit of body mass of an underweight individual and an obese individual, but there is individual variation in the energy expenditure by unit of body mass of individuals in general, which in practice limits the use of formulas that predict energy requirement. In relation to surgery, studies that use more sensitive methods are needed to confirm the hypothesis that the REE adjusted for LM after surgery does not decrease, by adaptation or modification mechanisms of body composition in LM no matter how long after surgery.

Type of fat tissue also appears to have a strong influence on energy expenditure. White fat tissue, in addition to working as a primary site for energy storage, produces a series of substances that act on many places of the body, modulating the general metabolism. Excess white fat tissue results in obesity. Meanwhile, brown fat tissue is highly specialized and is capable of regulating energy expenditure by adaptive thermogenesis. This process depends on UCP-1 expression (Cinti et al., 1997). White fat tissue is responsible for most of the leptin produced (Cinti et al., 1997), although the action of this peptide occurs in the hypothalamus, which is where most of its receptors are found (Schwartz et al., 1996). 
The total LM in the body is the factor that is most closely associated with leptin concentrations in the blood and so BMI, which is an indirect measurement of body fat, is also strongly and positively associated with the concentration of circulating leptin (Considine et al., 1996; Jeon et al., 2003; Kennedy et al., 1997). In a study done by our research group, the positive correlation between BMI and serum concentration of leptin was confirmed (Figure 5). This study assessed 45 women, of which 27 had less than $10 \%$ of weight regain 2 or more years after surgery and 18 presented an appropriate weight loss.

Another theme of interest relative to body composition is the role of FM by itself on the improvement of the comorbidities associated with obesity. Lowering of blood glucose (improvement of diabetes) in morbidly obese individuals after surgery occurs even before an important weight loss has been achieved and has been attributed to the modulation of the gastrointestinal hormonal response which acts in the recovery of the first phase of insulin secretion and improves its peripheral resistance (Polyzogopolou et al., 2003; Cummings et al., 2004). The important association of BMI with insulin and leptin concentrations in nondiabetic operated women (Figure 5) confirms the relevance of body weight reduction and maintenance for obtaining benefits after surgery. There was also a correlation of BMI with glucose concentration in women in the late postoperative period. Among the biochemical markers of lipid metabolism, an association between the concentrations of serum triglycerides with BMI was found, but not with total cholesterol and its fractions. The reduction of serum leptin that accompanies the reduction in body weight after bariatric surgery was inversely associated with the secretion of VLDL in studies of particle kinetics (Magkos, 2010), showing that the triglyceride metabolism has an important relationship with BMI.
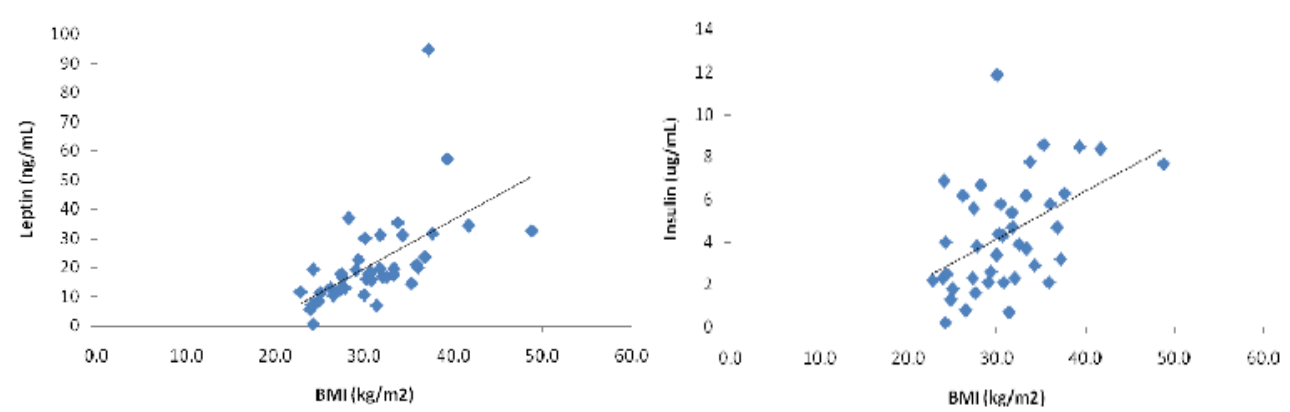

Fig. 5. Correlation of the serum leptin concentrations and insulin with body mass index (BMI) in women in the late postoperative period after Roux-en-Y gastric bypass $(n=41$, $\left.r=0.729 ; R^{2}=0.531 ; p=0.000\right)$, (Fogaça, 2009).

Finally, an aspect of great relevance associated with obesity and insulin resistance is the distribution of body fat. Not all obese individual are insulin-resistant, and it has been shown that predominantly abdominal obesity is more strongly associated with insulin resistance. Inflammation of the omental adipose tissue is an important determining factor of insulin resistance (Hardy, 2011). 


\section{Conclusions}

Energy balance is determined by energy intake and expenditure variables. Among the energy expenditure variables, REE and the expenditure with physical activities are responsible for roughly $90 \%$ of the TEE. Based on calorimetry studies, we have noticed that there is an important interpersonal variation in REE of women submitted to bariatric surgery. To know the magnitude of the effect of surgery on REE, we are conducting a prospective study to assess the interpersonal variation before surgery and after different lengths of postoperative time. Another aspect that needs to be better elucidated is the magnitude of the effect of physical exercise on REE in different lengths of postoperative periods.

In the energy requirement assessment, the use of prediction REE formulas does not seem adequate for the bariatric population and should be done with caution.

Physical activity is an important component of total energy expenditure and TEE assessment depends on precise information regarding the type and duration of each activity. As the energy intake registry, the registry of physical activity must be detailed and as close as possible of the real energy intake. This is a challenging task since among the obese, overestimation of the reported intake usually happens.

If, on the one hand, physical activities are usually overestimated, on the other hand, and more strikingly, food intake reports are usually underestimated. Among obese women, intake

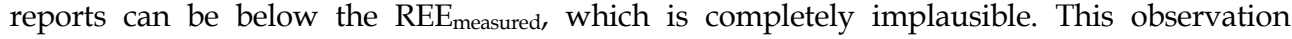
challenges us in the development of more appropriate methods to assess food intake.

BMI is an important indicator of the result of bariatric surgery and more studies are necessary on the effects of the distribution and type of body fat and the surgery results on the comorbidities associated with obesity.

\section{References}

Bazanelli, AP., Kamimura, MA., Vasselai, P., Draibe, SA. \& Cuppari, L. (2010). Underreporting of energy intake in peritoneal dialysis patients. Journal of Renal Nutrition, Vol. 20, No. 4, pp. 263-269, ISSN 1051-2276.

Beaton, GH. (1994). Approaches to analysis of dietary data: relationship between planned analyses and choice of methodology. The American Journal of Clinical Nutrition, Vol. 59, Supl. 1, pp. 253-261, ISSN 0002-9165.

Black, AE. (2000). Critical evaluation of energy intake using the Goldberg cut-off for energy intake: basal metabolic rate. A practical guide to its calculation, use and limitations. International Journal of Obesity, Vol. 24, No. 9, pp. 1119-1130, ISSN 0307-0565.

Black, AE. \& Cole, TJ. (2001). Biased over-or under-reporting is characteristic of individuals wheter over time or by different assessment methods. Journal of the American Dietetic Association, Vol. 101, No. 1, pp. 70-80, ISSN 0307-0565.

Black, AE., Goldberg, GR., Jebb, SA., Livingstone, MB., Cole TJ. \& Prentice AM. (1991). Critical evaluation of energy intake data using fundamental principles of energy physiology: 2. Evaluating the results of published surveys. European Journal of Clinical Nutrition, Vol. 45, No.12, pp. 583-599, ISSN 0954-3007.

Carriquiry, RH., Jensen, HH., Fuller, WA. \& Guenther, P. (1994). Methods for estimating usual intake distributions. The American Journal of Clinical Nutrition, Vol. 59, Suppl.1, pp. 305, ISSN 0002-9165. 
Cesar, MC., Montebelo, MIL., Rasera, I., Oliveira, AV., Gonelli, RG. \& Cardoso, GA. (2008). Effects of Roux-en-Y Gastric Bypass on Resting Energy Expenditure in Women. Obesity Surgery, Vol.18, No 11, pp. 1376-1380, ISSN 0960-8923

Cinti, S., Frederich, RC., Zingaretti, MC., De Matteis, R., Flier, JS. \& Lowell, BB. (1997). Imunohistochemical localization of leptin and uncoupling protein in white and brown adipose tissue. Endocrinology, Vol. 138, pp. 797-804, ISSN 0013-7227

Considine, RV., Sinha, MK., Heiman, ML.; Kriauciunas, A., Stephens, TW. NYCE, MR., Ohannesian, JP., Marco, CC., Mckee, LJ., Bauer, TL. \& Caro, JF. (1996). Serum immunoreactive leptin concentrations in normalweight and obese humans. The New England Journal of Medicine, Vol. 334, No. 5, pp. 292-295, ISSN 1533-4406.

Cowley, MA., Smith RG., Diano, S., Tschöp, M., Pronchuk, N., Grove, KL et al. (2003). The distribution and mechanism of action of ghrelin in the CNS demonstrates a novel hypothalamic circuit regulating energy homeostasis. Neuron, Vol. 37, No. 4, pp. 649-661, ISSN 0896-6273.

Cummings, DE., Overduin, J. \& Foster-Schubert, KE. (2004). Gastric bypass for obesity: mechanisms of weight loss and diabetes resolution. The Journal of Clinical Endocrinology \& Metabolism, Vol. 89, No. 6, pp. 2608-15. ISSN 0021-972X.

Dallemole, C. (2006). Avaliação da composição corporal e da taxa metabólica de repouso de mulheres jovens residentes no interior do estado de São Paulo/Brasil. 120 f. Dissertação (Mestrado em Educação Física - Performance Humana) - Universidade Metodista de Piracicaba/UNIMEP, Piracicaba/ SP.

Danforth, JE. (1985). Diet and obesity. The American Journal of Clinical Nutrition, Vol. 41, pp. 1132-1145, ISSN 1938- 3207.

Das, SK., Saltzman, E., McCrory, MA., Hsu, LK., Shikora, SA., Dolnikowski, G., Kehayias, JJ. \& Roberts SB. (2004). Energy expenditure in very high in extremely obese women. The Journal of Nutrition, Vol. 134, No. 6, pp. 1412-1416, ISSN 1541-6100.

Doucet, E., Pierre, S., Alméras, N., Mauriège, P., Richard, D. \& Tremblay, A. (2000). Changes in Energy Expenditure and Substrate Oxidation Resulting from Weight Loss in Obese Men and Women: Is There an Important Contribution of Leptin? The Journal of Clinical Endocrinology \& Metabolism, Vol. 85, No. 4. pp.1550-1556, ISSN 1945-7197.

Duarte, SFP., Francischetti, EA., Genelhu, VA., Duarte, SF., Francischetti, EA., Genelhu, VA., Cabello, PH. \& Pimentel MM. (2007). LEPR p.Q223R, $\beta 3-A R$ p.W64R and LEP c.2548G>A gene variants in obese brazilian subjects. Genetics and Molecular Research, Vol. 6, No. 4, pp. 1035-1043, ISSN 1676-5680.

Flatt, JP. The biochemistry of energy expenditure. In: Bray, GA. (1978). RecentAdvances in Obesity Research. Newman, London.

Flatt, JP. \& Tremblay, A. Energy expenditure and substrate oxidation. In: Bray, GA., Bouchard, C. \& James, WPT. (1998). Handbook of obesity. Marcel Dekker, New York.

Fogaça, KCP. (2009). Investigação de Fatores envolvidos na Recuperação de Peso após Derivação Gástrica. 121 f. Tese (Doutorado em Alimentos e Nutrição) - Universidade Estadual Paulista "Julio de Mesquita Filho" /UNESP, Araraquara/SP.

Food and Agriculture Organization, World Health Organization \& Organização das Nações Unidas (1985). Energy and protein requeriments. World Health Organization, WHO, Technical Report Series, 724, ISBN 924120724 8. Geneva.

Frankenfield, D., Yousey, LR. \& Compher, C. (2005). Comparison of predictive equations for resting metabolic rate in healthy nonobese and obese adults: a systematic review. Journal of the American Dietetic Association, Vol. 105, No. 5, pp. 775-789, ISSN 00028223. 
Gibson, RS. (2ed.). (2005). Principles of nutritional assessment, Oxford University, ISBN-10 0195171691, New York.

Goldberg, GR., Black, AE., Jebb, SA., Cole, TJ., Murgatroyd, PR., Coward, WA. \& Prentice, AM. (1991). Critical evaluation of energy intake data using fundamental principles of energy physiology: 1. Derivation of cut-off limits to identify under-recording. European Journal of Clinical Nutrition, Vol. 45, No. 12, pp. 569-581, ISSN 0954-3007.

Halaas, JL., Gajiwala, KS., Maffei, M., Cohen, SL., Chait, BT., Rabinowitz, D. et al. (1995). Weight-reducing effects of the plasma protein encoded by the obese gene. Science, Vol. 269, No. 5223, pp. 543-546, ISSN 1095-9203.

Hardie, LJ., Rayner, DV., Holmes, S. \& Trayhunr, P. (1996). Circulating leptin levels are modulated by fasting, cold exposure and insulin administration in lean but not Zucker (fa/fa) rats as measured by ELISA. Biochemical and Biophysical Research Communications, Vol. 223, No. 3, pp. 660-665, ISSN 0006-291X.

Hardy, OT., Perugini, RA., Nicoloro, SM., Gallagher-Dorval, K., Puri, V., Straubhaar, J. \& Czech, MP. (2011). Body mass index-independent inflammation in omental adipose tissue associated with insulin resistence in morbid obesity. Surgery for Obesity and Related, Vol. 7, No. 1, pp. 60-67, ISSN 1708-0428.

Harris, JA. \& Benedict, FA. (1919). A biometric study of basal metabolism in man, Carnegie Institution of Washington, Boston.

Hill, JO. (2006). Understanding and addressing the epidemic of obesity: an energy balance perpective. Endocrine Reviews, Vol. 27, No 7, pp. 750-761, ISSN 1945-7189.

Hill, JO., Sparling, PB., Shields, TW. \& Heller, PA. (1987). Effects of exercise and food restriction on body composition and metabolic rate in obese women. The American Journal of Clinical Nutrition, Vol. 46, No. 4, pp. 622-630, ISSN 1938- 3207.

Hill, JO., Melby, C., Johnson, SL. \& Peters, JC. (1995). Physical activity and energy requirements. The American Journal of Clinical Nutrition, Vol. 62, Suppl., pp. 1059S1066S, ISSN 1938- 3207.

Huang, TTK., Roberts, SR., Howarth, NC. \& McCrory, MA. (2005). Effect of screening out implausible energy intake reports on relationships between diet and BMI. Obesity Research, Vol. 13, No. 7, pp. 1205-1217, ISSN 1071-7323.

Institute of Medicine - IOM. (2005). Food and Nutrition Board. Dietary Reference Intakes (DRIs): Dietary Reference Intakes for Energy, Carbohydrates, Fiber, Fat, Protein and Amino Acids (Macronutrients). National Academy Press, Washington, D.C.

Jacobson, P., Rankinen, T., Tremblay, A., Pérusse, L., Chagnon, YC. \& Bouchard C. (2006). Resting metabolic rate and respiratory quotient: results from a genome-wide scan in the Quebec Family Study. The American Journal of Clinical Nutrition Vol. 84, No. 6, pp. 1527-1533, ISSN 0002-9165.

Jeon, JY., Steadward, RD., Wheeler, GD., Bell, g., Mccargar, L. \& Harber, V. (2003). Intact Sympathetic Nervous System Is Required for Leptin Effects on Resting Metabolic Rate in People with Spinal Cord Injury. The Journal of Clinical Endocrinology $\mathcal{E}$ Metabolism, Vol. 88, No. 1, pp. 402-407, ISSN 1945-7197.

Johansson, G., Wikman, A., Ahrén, AM., Hallmans, G. \& Johansson, I. (2001). Underreporting of energy intake in repeated 24 - hour recalls related to gender, age, weight status, day of interview, educational level, reported food intake, smoking habits and area of living. Public Health Nutrition, Vol. 4, No. 4, pp. 919-927, ISSN 1368-9800. 
Johansson, L., Solvoll, K., Björneoe, GE., \& Drevon, C. (1998). Under- and overreporting of energy intake related to weight status and lifestyle in a nationwide sample. The American Journal of Clinical Nutrition, Vol. 68, No. 2, pp. 266-274, ISSN 0002-9165.

Johnson, RK. (2002). Dietary intake - how do we measure what people are really eating? Obesity Research, Vol. 10, Suppl. 1, pp. 63-68, ISSN 1071-7323.

Kamegai, J., Tamura, H., Shimizu, T., Ishii S, Sugihara H \& Wakabayashi I. (2001). Chronic central infusion of ghrelin increases hypothalamic neuropeptide $\mathrm{Y}$ and Agoutirelated protein mRNA levels and body weight in rats. Diabetes, Vol. 50, No. 11, pp. 2438-2443, ISSN 0012-1797.

Kennedy, A., Gettys, T., Watson, P., Wallace, P., Ganaway, E., Pan, Q. \& Garvey, WT. (1997). The metabolic significance of leptin in humans: gender-based differences in relationship to adiposity, insulinsensitivity, and energy expenditure. The Journal of Clinical Endocrinology \& Metabolism, Vol. 82, No. 4, pp. 1293-1300, ISSN 1945-7197.

Körtzinger, I., Bierwag, A., Mast, M. \& Muller M.J. (1997). Dietary underreporting: validity of dietary measurements of energy intake using a 7-days dietary record and a diet history in non-obese subjects. Annals of Nutrition and Metabolism, Vol. 41, No. 1, pp. 37-44, ISSN 0250-6807.

Larson, DE., Tataranni, PA., Ferraro, RT., \& Ravussin, E. (1995). Ad libitum food intake on a "cafeteria diet" in native American women: relations with body composition and 24-h energy expenditure. The American Journal of Clinical Nutrition, Vol. 62, No. 5, pp. 911-917, ISSN 1938- 3207.

Leibel, RL., Rosenbaum, M. \& Hirsch, J. (1995). Changes in energy expenditure resulting from altered body weight. The New England Journal of Medicine, Vol. 332, No. 10, pp. 621-8, ISSN 1533-4406.

Livingstone, MB. \& Black, AE. (2003). Markers of the validity of reported energy intake. The Journal of Nutrition, Vol. 133, Suppl 3, pp. 895-920, ISSN 1541-6100.

Luis, DA., Aller, R., Izaola, O. \& Romero, E. (2006). Prediction equation of resting energy expenditure in adult Spanish of obese adult population. Annals of Nutrition and Metabolism, Vol. 50, No. 3, pp. 193-196, ISSN-1421-9697.

Magkos, F., Fabbrini, E., McCrea, J., Patterson, BW., Eagon, JC \&, Klein, S. (2010). Decrease in hepatic very-density lipoprotein-triglyceride secretion affer weight loss is inversely associated with changes in circulating leptin. Diabetes, Obesity and Metabolism, Vol. 12, No. 7, pp. 584-590, ISSN 1463-1326.

Marzullo, P., Verti, B., Savia, G., Walker, GE., Guzzaloni, G., Tagliaferri, M., et al. (2004). The relationship between active ghrelin levels and human obesity involves alterations in resting energy expenditure. The Journal of Clinical Endocrinology E Metabolism, Vol. 89, No. 2, pp. 936-939, ISSN 1945-7197.

Masuda, Y., Tanaka, T., Inomata, N., Ohnuma, N., Tanaka, S., Itoh, Z. et al. (2000). Ghrelin stimulates gastric adic secretion and motility in rats. Biochemical and Biophysical Research Communications, Vol. 276, No. 3, pp. 905-908, ISSN 0006-291X.

Mattevi, VS., Zembrzuski, VM. \& Hutz, MH (2002). Association analysis of genes involved in the leptin signaling pathway with obesity in Brazil. International Journal of Obesity, Vol. 26, No. 9, pp. 1179-1185, ISSN 0307-0565.

Matzinger, O., Schneiter, P. \& Tappy, L. (2002). Effects of fatty acids on exercise plus insulininduced glucose utilization in trained and sedentary subjects. American Journal of Physiology Endocrinology and Metabolism, Vol. 282, pp. E125-E131, ISSN 1522-1555. 
Maurer, J., Taren, D.L., Teixeira, PJ., Thomson, C., Lohman, TG., Going, SB. \& Houtkooper, LB. (2006). The psychosocial and behavioral characteristics related to energy misreporting. Nutrition Reviews, Vol. 64, No. 2, pp. 53-66, ISSN 1753-4887.

Maurer, J., Thomson, C., Ranger-Moore, J., Teixeira, PJ., Lohman, TG., Taren, DL., Cussler, E., Going, SB. \& Houtkooper, LB. (2008). Psychosocial and behavioral profile and preditors of self-reported energy underreporting in obese middle-aged women. Journal of the American Dietetic Association, Vol. 108, No. 1, pp.114-119, ISSN 00028223.

Meirelles, CM. \& Gomes, PSC. (2004). Efeitos agudos da atividade contraresistência sobre o gasto energético: revisitando o impacto das principais variáveis. Revista Brasileira de Medicina do Esporte, Vol. 10, No. 2, pp. 122-130, ISSN 1806-9940.

Mela, DJ. \& Rogers, PJ. (1998). Food, eating and obesity.Chapman \& Hall, London.

Melo, CM., Tirapegui, J. \& Ribeiro, SML. (2008). Gasto energético corporal: conceitos, formas de avaliação e sua relação com a obesidade, Arquivos Brasileiros de Endocrinologia $\mathcal{E}$ Metabologia, Vol. 52, No 3, pp. 452-464, ISSN 0004- 2730.

Mendez, MA., Popkin, BM., Buckland, G., Schroder, H., Amiano, P., Barricarte, A., Huerta, JM., Quirós, JR., Sánches, MJ. \& Gonzáles, CA. (2011). Alternative methods of accounting for underreporting and overreporting when measuring dietary intakeobesity relations. American Journal of Epidemiology, Vol. 173, No. 4, pp. 448-458, ISSN 1476-6256.

Mifflin, MD., Jeor, ST., Hill, LA., Scott, BJ., Daugherty, SA. \& Koh, YO. (1990). A new predictive equation for resting energy expenditure in healthy individuals. The American Journal of Clinical Nutrition, Vol. 51, No. 2, pp. 241-247, ISSN 1938- 3207.

Negrão, AB. \& Licinio, J. (2000.) Leptina: o diálogo entre adipócitos e neurônios. Arquivos Brasileiros de Endocrinologia \& Metabologia, Vol. 44, No. 3, pp. 205-214, ISSN 00042730.

Nusser, SM., Carriquiry, AL., Dood, KW. \& Fuller, WA. (1996). A semiparametric transformation approach to estimating usual daily intake distribuitions. Journal of American Statistical Association, Vol. 436, No. 91, pp. 1440-1449, ISSN 0162-1459.

Olafsdottir, AS., Thorsdottir, I., Gunnarsdottir, I., Thorgeirsdottir, H. \& Steingrimsdottir, L. (2006). Comparison of women`s diet assessed by FFQs and 24-hour recalls whith and without underreporters: association with biomarkers. Annals of Nutrition and Metabolism, Vol. 50, No. 5, pp. 450-460, ISSN 1421-9697.

Owen, OE., Kavle, E., Owen, RS., Polansky, M., Caprio, S., Mozzoli, MA., et al. (1986). A reappraisal of caloric requeriments in healthy women. The American Journal of Clinical Nutrition, Vol. 44, No. 1, pp. 1-19, ISSN-1938- 3207.

Polyzogopolou, EV., Kalfarentzos, F., Vagenakis, AG. \& Alexandrides, TK. (2003). Restoration of euglycemia and normal acute insulin response to glucose in obese subjects with type 2 diabetes following bariatric surgery. Diabetes. Vol. 52, No. 5, pp.1098-1103, ISSN 0012-1797.

Prentice, AM., Black, AE, Coward., WA, Davies, HL., Goldberg, GR., Murgatroyd, PR., Ashford, J., Sawyer, M. \& Whitehead RG. (1986). High levels of energy expenditure in obese women. British Medical Journal, Vol. 292, pp. 983-987, ISSN 09598138.

Prentice, AM. Are defects in energy expenditure involved in the causation of obesity? (2007).Obesity Reviews, Vol. 8, suppl. 1, pp. 89-91, ISSN 1467-789X. 
Probst, Y. \& Tapsell, L. (2007). Over-and underreporting of energy intake by patients with metabolic syndrome using an automated dietary assessment website. Nutrition $\mathcal{E}$ Dietetics, Vol. 64, pp. 280-284, ISSN 1747-0080.

Ravussin, E., Lillioja, S. \& Anderson, T. (1986). Determinants of 24-hour energy expenditure in man: methods and results using a respiratory chamber. The Journal of Clinical Investigation, Vol. 78, No. 6, pp. 1568-1578, ISSN 0021-9738.

Rennie, KL., Siervo, M. \& Jebb, SA. (2006). Can self-reported dieting and dietary restraint identify underreporters of energy intake in dietary surveys. Journal of the American Dietetic Association, Vol. 106, No. 10, p. 1667-1672, ISSN 0002-8223.

Rocha, EEM., Alves, VGF., Silva, MHN., Chiesa, CA. \& Fonseca, RBV. (2005). Can measured resting energy expenditure be estimated by formulae in daily clinical nutrition practice? Current Opinion in Clinical Nutrition \& Metabolic Care, Vol. 8, No. 3, pp. 319-328, ISSN 1363-1950.

Rosado, EL. \& Monteiro, JBR. (2001). Obesidade e a substituição de macronutrientes da dieta. Revista de Nutrição, Vol. 14, No. 2, pp. 145-152, ISSN 1415-5273.

Rutanen, J., Pihlajamäki, J., Karhapää, P., Vauhkonen, I., Kuusisto, J., Moilanen Mykkänen, L. \& Laakso, M. (2004). The Val103Ile Polymorphism of Melanocortin-4 Receptor Regulates Energy Expenditure and Weight Gain. Obesity Reasearch, Vol. 12, No. 7, pp. 1060 -1066, ISSN 1071-7323.

Sahu, A. Leptin signaling in the hypothalamus: emphasis on energy homeostasis and leptin resistance. (2004). Frontiers in Neuroendocrinology, Vol. 24, No. 4, pp. 225-53, ISSN 0091-3022.

Samaras, K.; Kelly, PJ. \& Campbell, LV. Dietary underreporting is prevalent in middleaged British women and is not related to adiposity (percentage body fat). (1999). International Journal of Obesity, Vol. 23, No. 8, pp. 881-888, ISSN 0307-0565.

Scagliusi, FB. Validade das estimativas de ingestão energética de três métodos de avaliação do consumo alimentar, em relação a água duplamente marcada. (2007). $185 \mathrm{f}$. Tese (Doutorado em Educação Física e Esporte) - Universidade de São Paulo/USP, São Paulo.

Scagliusi, FB., Ferrioli, E., Pfrimer, K., Laureano, C., Cunha CS., Gualano, B., Lourenço, BH. \& Lancha, AH. (2008). Underreporting of energy intake in Brazilian women varies according to dietary assessment: a cross-sectional study using doubly labeled water. Journal of the American Dietetic Association, Vol. 108, No. 12, pp. 2031-2040, ISSN 0002-8223.

Scagliusi, FB., Polacow, VO., Artioli, GG., Benatti, FB. \& Lancha, AH. (2003). Selective underreporting of energy intake in women: magnitude, determinants, and effect of training. Journal of the American Dietetic Association, Vol. 103, No. 10, pp. 1306-1313, ISSN 0002-8223.

Schoeller, DA. How accurate is self-reported dietary energy intake? (1990). Nutrition Reviews, Vol. 48, No 10, pp. 373-379, ISSN 1753-4887.

Schoeller, DA. Recent advances from application of doubly labeled water to mensurement of human energy expenditure. (1999). The Journal of Nutrition, Vol. 129, No. pp. 17651768, ISSN 1541-6100.

Schoeller, DA., \& Fjeld, CR. (1991). Human energy metabolism: what have we learned from the doubly labeled water method? Annual Review of Nutrition, Vol. 11, pp. 355-373, ISSN 0199-9885.

Schofield, WN. (1985). Predicting basal metabolic rate, new standards and review of previous work. Clinical Nutrition, Vol.39C (suppl), No1, pp. 5-41, ISSN 0261-5614. 
Schwartz, MW., Seeley, RJ., Campfield, LA., Burn, P. \& Baskin, DG. Identification of targets of leptin action in rat hypothalamus (1996). J Clin Invest, Vol. 98, pp.1101-6, ISSN 0021-9738.

Slater, B., Marchioni, DL. \& Fisberg, RM. (2004). Estimando a prevalência da ingestão inadequada de nutrientes. Revista de Saúde Pública, Vol. 38, No. 4, pp. 599-605, ISSN 1518-8787.

Smyrnios, NA. \& Curley, FJ. Indirect calorimetry. In Rippe, JM., Irwin, RS., Fink, MP. \& Cerra, FB. (1996). Intensive care medicine, 3a ed., Little, Brown. Boston.

Souza, CL. (2009). Fatores relacionados ao gasto e consumo energético de mulheres obesas com e sem síndrome metabólica. 121 f. Dissertação (Mestrado em Alimentos e Nutrição) Universidade Estadual Paulista. "Júlio de Mesquita Filho" / UNESP, Araraquara/ SP.

Subar, AF., Dood, KW., Guenther, PM., Kipnis, V., Midthune, D., Mcdowell, M. et al. (2006). The food propensity questionnaire: concept, development, and validation for use as a covariate in a model to estimate usual food intake. Journal of the American Dietetic Association, Vol. 106, No. 10, pp. 1556-1563, ISSN 0002-8223.

Svendsen, M. \& Tonstad, S. (2006). Accuracy of food intake reporting in obese subjects with metabolic risk factors. British Journal of Nutrition, Vol. 95, No.3, pp. 640-649, ISSN 1475-2662.

Tamboli, RA., Hossain, HA., Marks, PA., Eckhauser, AW., Rathmacher, JA., Philips, SE., Buchowski, MS., Chen, KY. \& Abumrad, NN. (2010). Body composition energy metabolism following Roux-en-Y gastric bypass surgery. Obesity, Vol. 18, No. 9, pp. 1718-1724, ISSN 1467-789X.

Tappy, L., Binnert, C. \& Schneiter, P. (2003). Energy expenditure, physical activity and bodyweight control. Proceedings Nutrition Society, Vol. 62, No 3, pp. 663-6, ISSN 14752719.

Tooze, JA., Subar, AF., Thompson, FE., Troiano, R., Schatzkin, A. \& Kipnis V. (2004). Psychosocial predictors of energy underreporting in a large doubly labeled water study. The American Journal of Clinical Nutrition, Vol. 79, No. 5, pp. 795-804, ISSN 1938- 3207.

Tortorella, C., Macchi, C., Spinazzi, R., Malendowicz, LK., Trejter, M. \& Nussdorfer, GG. (2003). Ghrelin, an endogenous ligand for the growth hormone-secretagogue receptor, is expressed in the human adrenal cortex. International Journal of Molecular Medicine, Vol. 12, No 2, pp. 213-217, ISSN 1791-244X.

Trayhurn, P., Thomas, ME., Duncan, JS. \& Rayner, DV. (1995). Effects of fasting and refeeding on ob gene expression in white adipose tissue of lean and obese $(\mathrm{ob} / \mathrm{ob})$ mice. FEBS Letters, Vol. 368, No. 3, pp. 488-490, ISSN 0014-5793.

Yurtcu, E., Yilmaz, A., Ozkurt, Z., Yurtcu, E., Yilmaz, A., Ozkurt, Z., Kolukisa, E., Yilmaz, M., Keles, H., Ergun, MA., Yetkin, I. \& Menevse A. (2009). Melanocortin-4 Receptor Gene Polymorphisms in Obese Patients. Biochemical Genetics, Vol. 47, No. 3, pp. 295300, ISSN 0006-2928.

Weijs, PJ. \& Vansant, GA. Validity of preditive equations for resting energy expenditura in Belgian normal weight to morbid obese women. (2010) Clinical Nutrition; Vol. 29, No. 3, pp. 347-351, ISSN 0261-5614.

Witschi JC. Short-term dietary recall and recording methods. In: Willett, W. (1990). Nutritional epidemiology. Oxford University Press, New York.

World Health Organization - WHO. (1998). Life in the 21st century: a vision for all. WHO, Geneve. 


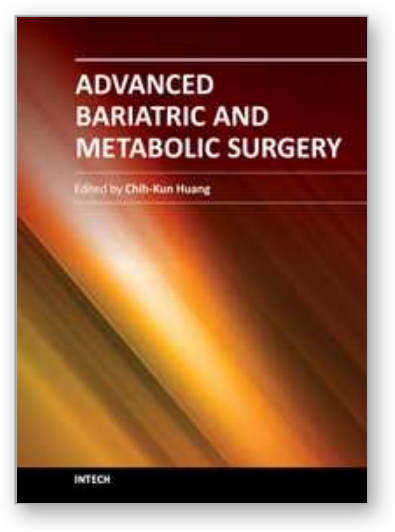

\author{
Advanced Bariatric and Metabolic Surgery \\ Edited by Dr. Chih-Kun Huang
}

ISBN 978-953-307-926-4

Hard cover, 326 pages

Publisher InTech

Published online 29, February, 2012

Published in print edition February, 2012

Bariatric surgery has gained importance in the last 20 years because of the high prevalence of global obesity, and the vast understating of the physiological and pathological aspects of obesity and associated metabolic syndromes. This book has been written by a number of highly outstanding authors and pioneering bariatric surgeons from all over the world. The intended audience for this book includes all medical professionals involved in caring for bariatric patients. The chapters cover the choice of operation, preoperative preparation including psychological aspect, postoperative care and management of complication. It also extends to concept and result of metabolic surgery and scarless bariatric surgery.

\title{
How to reference
}

In order to correctly reference this scholarly work, feel free to copy and paste the following:

Maria Rita Marques de Oliveira, Patrícia Fátima Sousa Novais, Karina Rodrigues Quesada, Carolina Leandro de Souza, Irineu Rasera Junior and Celso Vieira de Souza Leite (2012). Body Weight and Energy Intake and Expenditure in Bariatric Surgery, Advanced Bariatric and Metabolic Surgery, Dr. Chih-Kun Huang (Ed.), ISBN: 978-953-307-926-4, InTech, Available from: http://www.intechopen.com/books/advanced-bariatric-andmetabolic-surgery/body-weight-and-energy-balance-after-bariatric-surgery

\section{INTECH}

open science | open minds

\section{InTech Europe}

University Campus STeP Ri

Slavka Krautzeka 83/A

51000 Rijeka, Croatia

Phone: +385 (51) 770447

Fax: +385 (51) 686166

www.intechopen.com

\section{InTech China}

Unit 405, Office Block, Hotel Equatorial Shanghai

No.65, Yan An Road (West), Shanghai, 200040, China 中国上海市延安西路65号上海国际贵都大饭店办公楼 405 单元

Phone: +86-21-62489820

Fax: $+86-21-62489821$ 
(C) 2012 The Author(s). Licensee IntechOpen. This is an open access article distributed under the terms of the Creative Commons Attribution 3.0 License, which permits unrestricted use, distribution, and reproduction in any medium, provided the original work is properly cited. 